\title{
HEPATIC REGENERATION AFTER PARTIAL HEPATECTOMY IN MICE INFECTED WITH Schistosoma mansoni, AT THE ACUTE AND CHRONIC PHASES OF THE DISEASE
}

\author{
G. COSTA(1), J.R. CUNHA-MELO(1,3), B.G. AgUIAR(1), S.C. GONÇALVES(1), N.H. TOPPA(2) \& P.M.Z. COELHO(4,5)
}

\begin{abstract}
SUMMARY
Outbred male albino mice normal or infected with 30 cercariae of Schistosoma mansoni (LE strain) were submitted to $65 \%$ hepatectomy during the acute (70 days) and chronic phase (160 days) phases of the disease. A group of the infected animals was treated with $400 \mathrm{mg} / \mathrm{kg}$ of oxamniquine during the acute phase before hepatectomy. Non-infected, infected and treated but not hepatectomized animals were kept as controls.

Hepatic regeneration was evaluated by incorporation of tritiated thymidine, intraperitoneally injected into non-hepatectomized and hepatectomized animals, 24 hours after surgery. The results showed that removal of $65 \%$ of the hepatic parenchyma, during the acute phase, led to a statistically significant increase of thymidine incorporation, when compared with the uninfected hepatectomized controls. This phenomenon was not observed at the chronic phase. Treatment with oxamniquine administered during the acute phase led to a decrease in thymidine incorporation rate 160 days after infection ( 90 days after treatment) and 24 hours after hepatectomy.

The data suggest that infection with $S$. mansoni represents a considerable stimulus for the regenerative capacity of the liver during the acute, but not the chronic phase of disease.
\end{abstract}

KEYWORDS: Schistosoma mansoni; Liver regeneration; Hepatectomy; Thymidine incorporation.

\section{INTRODUCTION}

Schistosoma mansoni is a parasite that infects millions of individuals in various regions of the world. The eggs that are laid in tissues are fundamental elements in the pathogeny of the disease, being the liver the most affected organ.

Hepatic regeneration in murine schistosomiasis was studied after partial hepatectomy $(30 \%)^{26}$ but only during the acute phase of the disease, and with removal of a small amount of parenchyma, that was not able to promote an adequate regenerative stimulus. Regeneration of the normal liver takes place in an accelerated manner, when $60 \%$ of the parenchyma is removed ${ }^{3,14,28}$. Insufficient removal of the hepatic parenchyma (up to $30 \%$ ), in chronic murine schistosomiasis, showed that the numbers of labelled hepatocytes in the animals bearing schistosomotic fibrosis were lower than in controls at 24, 48 and 72 hours after hepatectomy ${ }^{29}$ as demonstrated by autoradiography. There are few published papers dealing with hepatic regeneration in experimental schistosomiasis in spite of the importance of this disease. The aim of the present investigation was to study the effect of partial hepatectomy ( $65 \%$ of parenchyma) on the hepatic regeneration of mice infected with $S$. mansoni during the acute (70 days) and chronic (160 days) phases of the disease, and the effect of treatment with oxamniquine at the acute phase on liver regeneration.

\section{MATERIAL AND METHODS}

Animals - A total of 102 outbred male albino mice, weighing about 25 $\mathrm{g}$ at the beginning of the experiment, were used.

S. mansoni - The LE strain of $S$. mansoni, isolated from faeces of a patient living in Belo Horizonte, MG, Brazil, and maintained under laboratory conditions for more than 30 years, was used in the experiments.

Infection of animals - Mice were infected with 30 cercariae, by subcutaneous injection.

Chemotherapeutic treatment - The animals were treated with a single dose of $400 \mathrm{mg} / \mathrm{kg}$ oxamniquine (Mansil, Pfizer Laboratory), by the oral route ( $\mathrm{n}=16)$ at 70 days post-infection (acute phase of the disease), according to COELHO \& TAVARES, $1991^{6}$.

Assessment of worm burden and efficacy of chemotherapeutic treatment - Five infected and untreated animals, and five oxamniquinetreated animals were sacrificed by cervical fracture and submitted to perfusion for worm recovery ${ }^{21} 30$ days after treatment. The control group showed a mean worm recovery of 15 worms/animal. In the treated group no worm was recovered.

(1) Department of Surgery, School of Medicine, Federal University of Minas Gerais, MG, Brazil.

(2) Department of Pathologic Anatomy, School of Medicine, Federal University of Minas Gerais, MG, Brazil.

(3) GEN-CAD Service, Federal University of Minas Gerais, MG, Brazil.

(4) Department of Parasitology, Institute of Biological Sciences, Federal University of Minas Gerais, MG, Brazil.

(5) "Santa Casa de Misericórdia", Belo Horizonte, MG, Brazil

Correspondence to: Prof. Paulo Marcos Zech Coelho, GIDE - ICB/UFMG, Caixa Postal 486, 30161-970 Belo Horizonte, MG, Brazil. 


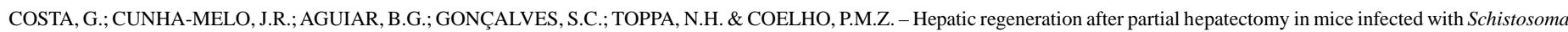
mansoni, at the acute and chronic phases of the disease. Rev. Inst. Med. trop. S. Paulo, 41(4): 255-258,1999.

Surgical procedures - Hepatectomy was performed on days 70 and 160 after infection and 90 days after oxamniquine treatment according to a previously described technique ${ }^{14}$. The animals were submitted to inhalatory anesthesia with enflurane. Antisepsis of the abdominal skin was disinfected with povidone-iodine and a $3.0 \mathrm{~cm}$ median laparotomy was performed. The abdominal cavity was exposed and the falciform and hepatogastric ligaments were cut. The median and left lateral lobes were extirpated after individual ligature of their basis with 000 silk thread. Laparorrhaphy was carried out on a single layer, by means of continuous suture with 000 poliglycolic acid thread. The animals were maintained in a heated room until total recovery from anesthesia.

Injection of tritiated thymidine - Twenty-four hours after hepatectomy, the animals were inoculated intraperitoneally with tritiated thymidine (Methyl-3H, $20.00 \mathrm{Ci} / \mathrm{mMol}$, Du Pont), at the dose of $0.5 \mu \mathrm{Ci} / \mathrm{g}$ body weight.

Recovery of the livers - Twenty-four hours after inoculation with thymidine, the animals were sacrificed by inhalation of sulfuric ether and the livers removed, weighed and kept at $-20{ }^{\circ} \mathrm{C}$.

Evaluation of tritiated thymidine incorporation rate - The livers were thawed and transferred to test tubes containing $5 \mathrm{ml}$ of distilled water and sonicated with supersonic sound waves until the total desintegration of the cells. Small amounts of distilled water to a final dilution of 1:10 $(\mathrm{m} / \mathrm{v})$ were added and $0.4 \mathrm{ml}$ were transferred to a different test tube. A volume of $2 \mathrm{ml}$ of NCS tissue solubilizer was added and the test tubes were kept at room temperature until total solubilization of the homogenate. A sample of $0.5 \mathrm{ml}$ of this solution was transferred to a 4 $\mathrm{ml}$ vial and $3 \mathrm{ml}$ of Bray's scintillation solution for the determination of CPM (countings per minute). The $24 \mathrm{~h}$-period for evaluation of thymidine incorporation was based on published methods ${ }^{4}$.

Statistical analysis - Data were analyzed by one-way analysis of variance with $\mathrm{p}<0.05$ being considered significant.

\section{RESULTS}

Table 1 shows that $65 \%$ hepatectomy induces an increase in thymidine incorporation in normal mice, when compared to normal intact mice $(p<0.042)$. The acute phase of schistosomiasis led to a significant increase of thymidine incorporation when compared with the respective infected control groups $(\mathrm{p}<0.0003)$. The presence of $S$. mansoni, by itself, during the acute phase increased significantly the incorporation rate, when compared with the uninfected intact animals ( $p<0.0000086)$.

During the chronic phase of the disease (160 days after infection), $65 \%$ hepatectomy led to an increase of thymidine incorporation in both infected and uninfected animals (Table 2). During that phase of the disease, no statistically significant differences were detected between infected and non-hepatectomized normal. In the oxamniquine-treated animals (400 mg/kg), in acute phase (70 days), no statistically significant differences between hepatectomized and normal animals were detected. However, this last group showed a marked decrease of thymidine incorporation $(\mathrm{p}<0.0002)$, when compared with the untreated normal group - hepatectomized or not, and infected group, hepatectomized or not.
The perfusion of 5 mice submitted to treatment with $400 \mathrm{mg} / \mathrm{kg}$ oxamniquine, 30 days after drug administration, did not detect surviving worms. The mortality rate after surgery was very low in all the animal groups studied.

\section{Table 1}

Rate of tritiated thymidine incorporation by the hepatic parenchyma in hepatectomized mice, at 70 days after infection with Schistosoma mansoni

\begin{tabular}{lc}
\hline Group & Scintillations per minute \\
\hline Normal $(\mathrm{n}=10)$ & $551 \pm 98$ \\
Normal hepatectomized $(\mathrm{n}=10)$ & $789 \pm 113 *$ \\
Infected $(\mathrm{n}=10)$ & $937 \pm 165 * *$ \\
Infected hepatectomized $(\mathrm{n}=10)$ & $2684 \pm 1138 *$ \\
\hline
\end{tabular}

$* \mathrm{p}<0.042 ; * * \mathrm{p}<0.0000086$, when compared with normal animals; $\# \mathrm{p}<0.0003$, when compared with infected animals.

Table 2

Rate of tritiated thymidine incorporation by the hepatic parenchyma in hepatectomized mice, at 160 days after infection with Schistosoma mansoni, and at 90 days after treatment administered at the acute phase

\begin{tabular}{lc}
\hline Group & Scintillations per minute \\
\hline Normal $(\mathrm{n}=12)$ & $765 \pm 91$ \\
Normal hepatectomized $(\mathrm{n}=11)$ & $837 \pm 64 *$ \\
Infected $(\mathrm{n}=8)$ & $697 \pm 96 \bullet$ \\
Infected hepatectomized $(\mathrm{n}=5)$ & $846 \pm 128 * *$ \\
Treated $(\mathrm{n}=10)$ & $540 \pm 132 \#$ \\
Treated hepatectomized $(\mathrm{n}=6)$ & $535 \pm 99 \# \#$ \\
$* \mathrm{p}<0.042 ; * * \mathrm{p}<0.03 ; \# \mathrm{p}<0.00013 ; \# \# \mathrm{p}<0.00016 ; \bullet \mathrm{p}<0.12$, \\
when compared with normal animals.
\end{tabular}

\section{DISCUSSION}

The phenomenon of hepatic regeneration was described a long time ago. Grecian mythology includes the legend of Prometheus, whose liver was partially eaten by an eagle, that returned everyday and repeated the torture after regeneration of the organ.

The mechanisms related to hepatic regeneration show a complex interaction among biochemical, genetic, physical and environmental processes. The regeneration varies according to the studied species, age of the animal, diet, amount of removed hepatic portion, diurnal luminosity and hepatic diseases ${ }^{18}$. A number of gene induce the production of several growth factors, such as hepatocyte growth factor (HGF), epidermal growth factor (EGF), transforming growth factor- $\propto$ (TGF- $\propto)$, interleukin6 , tumor necrosis factor (TNF), insuline, and norepinephrine among the most important ${ }^{18,25}$. 
An experimental model, consisting of rats submitted to hepatectomy $60 \%$, was the basis for the technique ${ }^{14}$. The removal of specific hepatic lobes induced an accelerate hepatic regeneration, with the recovery of the original hepatic biomass, 5-7 days after surgery. In this experiment, we used mice since the acute and chronic phases, and the lesions caused by granulomatous reactions around the eggs in tissues, in this model are very similar to the ones detected in human disease $\mathrm{e}^{9,17,27}$.

There are few reports in the literature concerning the phenomenon of hepatic regeneration in experimental schistosomiasis following partial hepatectomy in mice ${ }^{26}$, or rats ${ }^{1,12}$, which are considered inadequate hosts for $S$. mansoni ${ }^{19,22}$.

Removal of up to $30 \%$ of the hepatic parenchyma at the acute phase of schistosomiasis resulted in a weak regenerative stimulus similar to what was observed in normal animals ${ }^{26}$ in agreement with previous data for normal animals ${ }^{4,10,28}$. The differences detected between previously published results ${ }^{26}$ and the present data, which show significant thymidine incorporation in the animals hepatectomized during the acute phase, were certainly due to the removal of about $65 \%$ of the hepatic parenchyma ${ }^{4,14}$. Care must be taken before considering the result of thymidine incorporation in the liver of animals as the sole cause of the phenomenon of hepatic regeneration considering that mitoses, which occur in the inflammatory process, could be responsible for the consumption of thymidine in the synthesis of deoxyribonucleic acid ${ }^{20,26}$. S. mansoni eggs are also able to incorporate radioactive thymidine ${ }^{24}$. The present data showed a markedly higher thymidine incorporation in hepatectomized animals, only during the acute phase. Considering that there are eggs in tissues during both the acute and chronic phases, the inflammatory response induced by the presence of eggs cannot explain the increase of thymidine incorporation. Nevertheless, the inflammatory reactions and the cellular infiltrate in granulomas are more pronounced in the acute phase. Despite these considerations we believe that the exacerbated inflammatory reaction per se would not be sufficient to explain the very high rates of thymidine incorporation, that were detected in the infectedhepatectomized group during the acute phase (Table 1).

The different lymphokines produced during the acute and chronic phases could play a significant role in the liver regenerative kinetics. Production of IL-2, gamma interferon and TNF, produced by TH1 of CD4+ cells during the acute phase of schistosomiasis, have been described. TNF activates transcription factors at the beginning of hepatic regeneration ${ }^{11}$, and this could justify, at least in part, the marked thymidine incorporation detected, during the acute phase in the present study. Conversely, during the chronic phase of schistosomiasis, the $\mathrm{TH} 2$ subpopulation of CD4+ cells predominates, with production of IL4 and IL5, besides the appearance of IL10, the latter being an important factor responsible for the transition from the acute to the chronic phase $2,5,16,23$.

The drug treatment of experimental schistosomiasis enables the animals to modulate the granulomatous response up to 200 days after cure. When reinfected these animals can reduce the intensity of the inflammatory response to egg antigens, as well as avoid a new acute phase $^{7,8}$. The present study showed that a decrease in the regenerative capacity of treated animals ( 90 days after treatment), might be due to the absence of living parasite stimuli, as well as to a remaining immunomodulatory capacity that impairs the production of lymphokines seen at the acute phase.
Finally, it is interesting to note that although of hepatic regeneration phenomena in schistosomiasis are accepted as a fascinating subject, they have not been extensively studied and constitute a broad research field to be explored.

\section{RESUMO}

Regeneração hepática após hepatectomia parcial em camundongos infectados com Schistosoma mansoni, nas fases aguda e crônica da doença

Camundongos albinos não-isogênicos, normais ou infectados com 30 cercárias de Schistosoma mansoni (cepa LE) foram submetidos a hepatectomia parcial $(65 \%)$ na fase aguda (70 dias) ou crônica (160 dias) da doença. Um grupo de animais infectados foi tratado, na fase aguda, com $400 \mathrm{mg} / \mathrm{kg}$ oxamniquine antes da hepatectomia. Animais não infectados, infectados e tratados mas não hepatectomizados, foram mantidos como controles.

A regeneração hepática foi avaliada pela incorporação de timidina tritiada, injetada peritonealmente em animais hepatectomizados ou não, 24 horas após cirurgia. Os resultados mostraram que a remoção de $65 \%$ do parênquina hepático, na fase aguda, levou a um aumento estatisticamente significativo da incorporação de timidina, quando comparado com os animais controles (não infectados e hepatectomizados). Este fenômeno não foi observado na fase crônica. $\mathrm{O}$ tratamento com oxamniquina, administrado na fase aguda, levou a uma diminuição da taxa de incorporação de timidina, 160 dias após infecção (90 dias após tratamento) e 24 horas após hepatectomia. Os dados obtidos sugerem que a infecção com $S$. mansoni representa um estímulo considerável para a capacidade regeneradora do fígado na fase aguda, mas não na fase crônica da doença.

\section{ACKNOWLEDGEMENTS}

This work was supported in part by CNPq-PRONEX, FINEP and FAPEMIG, Brazil.

\section{REFERENCES}

1. AGUIAR, J.L.A.; FERRAZ, E.M.; BACELAR, T.S.; FERREIRA FILHO, H.A. \& KELNER, S. - Regeneração hepática após hepatectomia parcial em ratos com fibrose esquistossomótica, antes e após tratamento medicamentoso. An. paul. Med. Cirurg., 109: 29-40, 1982.

2. BOROS, D.L. - Immunopathology of Schistosoma mansoni infection. Clin. Microbiol. Rev., 2: 250-269, 1989.

3. BUCHER, N.R.L. - Experimental aspects of hepatic regeneration. New Engl. J. Med., 277: 686-696, 1967

4. BUCHER, N.R.L \& SWAFFIELD, M.N. - The rate of incorporation of labelled thymidine into the deoxyribonucleic acid of regenerating rat liver in relation to amount of liver excised. Cancer Res., 24: 1611-1625, 1964.

5. CHEEVER, A.W.; XY, I.; MACEDONIA, J.G.; HIENEY, S. \& SHER, A. - The role of cytokines in the pathogenesis of hepatic granulomatous disease in Schistosoma mansoni infected mice. Mem. Inst. Oswaldo Cruz, 87: 81-85, 1992. 


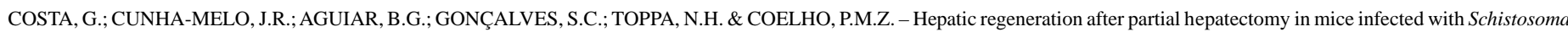
mansoni, at the acute and chronic phases of the disease. Rev. Inst. Med. trop. S. Paulo, 41(4): 255-258,1999.

6.COELHO, P.M.Z. \& TAVARES, C.A.P. - ELISA detection of specific circulating antibodies against Schistosoma mansoni in mice after treatment with oxamniquine. Braz. J. med. biol. Res., 24: 485-493, 1991.

7. COELHO, P.M.Z; RASO, P.; MELLO, R.T. \& TOPPA, N.H. - Schistosoma mansoni in mice: modulation of granulomatous response after reinfection and chemotherapeutic treatment. Rev. Soc. bras. Med. trop., 27: 119-125, 1994.

8. COELHO, P.M.Z.; TOPPA, N.H.; FELDMAN, J.S; GONÇALVES, R. \& MELLO, R.T. Schistosoma mansoni: permanence of modulation of granulomatous inflammatory response in mice cured in the chronic phase. Int. J. Parasit., 12: 1393-1395, 1996.

9. DE WITT, W.B. \& WARREN, K.S. - Hepatosplenic schistosomiasis in mice. Amer. J. trop. Med. Hyg., 8: 440-446, 1959.

10. FABRYKANT, J.I. - The kinetics of cellular proliferation in regenerating liver. J. Cell Biol., 36: 551-565, 1968.

11. FAUSTO, N.; LAIRD, A.D. \& WEBBER, E.M. - Liver regeneration. 2. Role of growth factors and cytokines in hepatic regeneration. FASEB J., 9: 1527-1536, 1995.

12. FERRAZ, E.M.; AGUIAR, J.L.A.; CARNEIRO JR., J.C.P. \& KELNER, S. - Regeneração hepática no rato albino infectado com Schistosoma mansoni e submetido a hepatectomia parcial. Rev. Col. bras. Cirurg., 6: 173-179, 1974.

13. FRAYSSINET, C.; GRESSER, I.; TOVEY, M. \& LINDANE, P. - Inhibitory effect of potent interferon preparations on the regeneration of mouse liver after partial hepatectomy. Nature (Lond.), 245: 146-147, 1973.

14. HIGGINS, G.M. \& ANDERSON, R.M. - Experimental pathology of the liver. I. Restoration of the liver of the white rat following surgical partial removal. Arch. Path., 12: 186202, 1931.

15. KREN, B.T \& STEER, C.J. - Post-transcriptional regulation of gene expression in liver regeneration: role of mRNA stability. FASEB J., 10: 559-573, 1996.

16. MALAQUIAS, L.C.C.; FALCÃO, P.L.; SILVEIRA, A.M.S. et al. - Cytokine regulation of human immune response to Schistosoma mansoni: analysis of role of IL-4, IL-5 and IL-10 on peripheral blood mononuclear cell responses. Scand. J. Immunol., 46: 393-398, 1997.

17. MELENEY, H.E.; SANDGROUND, J.H.; MOORE, D.V.; MOST, H. \& CARNEY, B.H. - The histopathology of experimental schistosomiasis. II. Bisexual infection with Schistosoma mansoni, Schistosoma japonicum and Schistosoma haematobium. Amer. J. trop. Med. Hyg., 2: 883-913, 1953.
18. MICHALOPOULOS, G.K. \& DE FRANCE, M.C. - Liver regeneration. Science, 276: 59-66, 1997

19. MOORE, D.V.; YOKKES, T.K. \& MELENEY, H.E. - A comparison of common laboratory animals as experimental hosts for Schistosoma mansoni. J. Parasit., 35: 156-170, 1949

20. ORREGO, H.; ISRAEL, J.Y.; CROSSLEY, I.R. et al. - Effect of chronic alcohol intake on hepatic fibrosis and granulomas in murune schistosomiasis mansoni. Hepatology, 1: 416-418, 1981.

21. PELLEGRINO, J. \& SIQUEIRA, A.F. - Ténica de perfusão para colheita de Schistosoma mansoni em cobaias experimentalmente infectadas. Rev. bras Malar., 8: 589-597, 1956

22. PHILLIPS, S.M. \& COLLEY, D.G. - Immunologic aspects of host responses to schistosomes: resistance, immunopathology and eosinophil involvement. Progr. Allergy, 2: 49-52, 1978.

23. STADECKER, M.J. \& VILLANUEVA, P.O.F. - Accessory cell signals regulate TH cell responses: from basic immunology to a model of helminthic disease. Immunol. today, 15: $571-574,1994$

24. STJERNHOLN, R.L. \& WARREN, K.S. - Schistosoma mansoni: utilization of exogenous metabolites by eggs “in vitro". Exp. Parasit., 36: 222-232, 1974.

25. TAUB, R. - Transcriptional control of liver regeneration. FASEB J., 10: 413-427, 1996.

26. TEIXEIRA, C.C. \& ANDRADE, Z. - Hepatic regeneration following partial hepatectomy in mice infected with Schistosoma mansoni. Braz. J. med. biol. Res., 18: 201-205, 1985 .

27. WARREN, K.S. - Immunopathogenesis of schistosomiasis: a multidisciplinary approach Trans. roy. Soc. trop. Med. Hyg., 63: 417-434, 1972.

28. YOKOYAMA, H.O.; WILSON, N.E.; TSUBOI, K.K. \& STOWELL, R.E. - Regeneration of mouse liver after partial hepatectomy. Cancer Res., 13: 80-85, 1953.

29. ZUCOLLOTO, S.; SILVA, J.C.; SILVA JR., O.C.; GONZAGA, E.Z.S. \& FABRO, A.L.D. - Hepatic regeneration after hepatectomy in schistosomotic fibrosis. Int. J. exp. Path., 71: 465-468, 1990 .

Received: 04 February 1999

Accepted: 16 April 1999 